In 1898 he became director of the Giza Zoological Gardens and occupied this post until his retirement in 1924. He made several journeys to the Upper Nile and was responsible for drafting the laws of the Game Preservation Department of the Sudan Government. He also took an active part in the protection of fauna, and thanks mainly to his efforts egrets are now once again common in Egypt. By 1912 plumage hunters had reduced them to only two small colonies, but after protective legislation had been introduced they soon multiplied, and I remember the pride it always gave Flower to see these beautiful birds coming in their hundreds at sundown to roost in the trees in the Giza Zoological Gardens.

Flower served during the First World War as commander of the Camel Transport Corps and later in the Frontier Districts Administration; he was awarded the O.B.E., the Order of the Nile, and of the Medjidieh, and mentioned in dispatches.

After his retirement, he took an active interest in the Zoological Society of London, and served on its Council during 1924-36, and was vice-president during 1927-29. He was also chairman of the British Ornithologist's Club (1930-32), and an honorary member of various foreign societies.

Flower's many zoological publications include "The Mammalia of Siam and the Malay Peninsula" (1900); a series of reports on the Giza Zoological Gardens, containing much useful information; mammals and reptiles in "The List of Vertebrated Animals exhibited in the Gardens of the Zoological Society of London" (1927); and his papers on the duration of life in animals (1925 et seq.), many of them based on personal observations and breeding experiments which he continued to the end of his life. A note on the duration of life in woodlice, by W. E. Collinge, based on Flower's observations, appeared in Nature as recently as December 22, 1945 (p. 755). Edward HindLE.

\section{Prof. Heinrich Rausch v. Traubenberg}

Ir is more than a year ago since $I$ heard of the tragic death of my friend Traubenberg; but only now have I got authentic news about his fate.

Traubenberg was born on March 17, 1880, in Estonia, a descendant of one of the ancient families who ruled those provinces for centuries. These 'Baltic Barons' combined great activity in "administration and politics under the Czars with an extremely high level of culture in their private lives. Traubenberg, though free from worldly ambitions, was deeply imbued with that cultural inheritance of his ancestors. He studied at the Universities of Leipzig, Freiburg and Würzburg, where he graduated under W. Wien in 1905 with a thesis on the Hall effect.

In the following years he worked in the laboratories of different electrical engineering firms in Berlin, but returned soon to scientific research in Leipzig, Würzburg and St. Petersburg. In 1910 he went to Göttingen, where I first met him. He was gentle and kind, quiet and modest, a hard worker and keen thinker. As soon as he discovered that I shared his enthusiasm for physics we became friends. In him there burned a genuine-fire for all that was great and noble. He loved discussions on philosophy, art, science, religion, and was a splendid opponent in an argument, full of wit and humour. I shall never forget those evenings of friendly controversy backed by a bottle of good Burgundy.

In 1912 Traubenberg became a lecturer (Privat. Dozent) at Göttingen. After the death of Prof. E.
Riecke, in 1915, he was deputy director of the laboratory for several years. In 1922 he was called to a chair at the German University in Prague, and in 1931 he succeeded Geiger in Kiel.

Traubenberg's work covers a wide field. During his stay in Göttingen, he determined the ranges of $\alpha$-particles in liquids and solids, a work much appreciated by Rutherford. Among many papers of his on radioactivity I may mention his measurement of the solubility of radium emanation in water, by which it was shown that Henry's law is valid for these extremely minute amounts of rare gases. Later his interest was concentrated on positive rays. He investigated the Stark effect in rapidly changing and in extremely strong electric fields. Shortly after Ruther. ford's discovery of the artificial disintegration of nuclei, Traubenberg showed that the lithium nucleus could be split by protons of as little energy as $30,000 \mathrm{eV}$., and he investigated the penetrating radiation accompanying this process. His last papers, written in extremely difficult circumstances, are mostly concerned with neutrons.

Traubenberg had never yielded to the Nazi creed of race-and militarism, and therefore lost his chair at the University of $\mathrm{Kiel}$ in 1937. His attempts to leave Germany wore not successful. After having overcome a bad nervous breakdown he took up work in an industrial laboratory in Berlin, but returned later to pure research in a little private laboratory, with no other help than that of his wife, on problems of nuclear physics. In 1944 his house was burned down in an air-raid. The Traubenbergs found refuge in Hirschberg, Bohemia, on the estate of Count Karl Waldstein. He was beginning to work again on his beloved experiments when his wife was arrested by the S.S. He collapsed and died a few hours later, on September 19, 1944.

Max BORN.

\section{Dr. L. Kuščer}

Mr. R. S. Hawes, University College, Exeter, has learned from Dr. Jovan Hadži, professor of zoology in the University of Ljubljana, that Dr. L. Kuščr, the well-known malacologist, died in 1943, after imprisonment by the Italians. Dr. Kušcer was an authority on the cavicolous snails of Jugoslavia, and, in spite of difficulties which would have defeated a lesser enthusiast - he lived in constant ill-health and in something near to poverty-he had assembled an unrivalled collection of his material. He was an incorrigible idealist and admirer of Britain. British zoologists whose work took them to Slovenia will remember his cheerful, untiring helpfulness and simple, but charming, hospitality.

Wre regret to announce the following deaths :

Mr. R. Engelbach, technical adviser to the Antiquities Department, Egyptian Government, since 1942, and author with the late Mr. Somers Clarke of "Ancient Egyptian Masonry", on February 26, aged fifty-seven.

Dr. F. W. Lanchester, F.R.S., consulting engineer on March 8, aged seventy-seven.

Dr. Max Poser, special technical representative of the Bausch and Lomb Optical Co., who contributed to the design of many eye examination instruments, such as the Ives visual acuity apparatus, the stereo campimeter and the Poser slit lamp, on January 4, aged seventy-five. 